GASTRODNTIROLOEY

$8 \mathrm{med} \cdot 9 \geq 139$

101
1991

$1-576$ 
1 This Month in GASTROENTEROLOGY

\section{ALIMENTARY TRACT}

3 Sensitivity of the Gastric Mucosa to Acid and Duodenal Contents in Patients With Nonulcer Dyspepsia A.A. George, M. TSUCHIYose, AND C.P. DOOLEY

7 Phospholipid-and Neutral Lipid-Containing Organelles of Rat Gastroduodenal Mucous Cells

Y.-C.J. KAO AND L.M. LICHTENBERGER

22 Acute Intestinal Injury Induced by Acetic Acid and Casein: Prevention by Intraluminal Misoprostol M.J.S. Miller, X.-J. Zhang, X. GU, AND D.A. ClaRK

31 T-Lymphocyte Modulation of Intestinal Muscle Function in the Trichinella-Infected Rat

D.L. VERMILLION, P.B. ERNST, AND S.M. Collins

39 Use of Azathioprine or 6-Mercaptopurine in the Treatment of Crohn's Disease

J.J. O'BRIEN, T.M. BAYLESS, AND J.A. BAYLESS

47 Localization of Endothelinlike Immunoreactivity and Endothelin Binding Sites in Human Colon

H. INAGAKI, A.E. BISHOP, C. ESCRIG, J. WHARTON,

T.G. ALlen-MERSH, AND J.M. POLAK

55 The Mechanism of Action of Peppermint Oil on Gastrointestinal Smooth Muscle

J.M. HILLS AND P.I. AARONSON

66 Gastric Acid Secretion and Parietal Cell Mass: Effect of Sex Hormones

K.A. ADENIYI

70 Proliferation of Endocrine Cells in the Rat Stomach Caused by Drug-Induced Achlorhydria

R. EISSElE, B. ROßKOPF, H. KOOP, G. AdLER, AND R. ARNOLD

77 A Novel Enzyme Immunoassay for Serodiagnosis of Helicobacter pylori Infection

T. Sugiyama, K. Imai, H. Yoshida, Y. Takayama, T. Yabana, K. YOKOTA, K. OGUMA, AND A. YaCH

84 The Effect of Elemental Diet on Intestinal Permeability and Inflammation in Crohn's Disease

K. Teahon, P. Smethurst, M. Pearson, A.J. Levi, AND I. BJARNASON

90 Lamina Propria Lymphocytes Are Derived From Circulating Cells That Lack the Leu-8 Lymph Node Homing Receptor M. BERG, Y. Murakawa, D. CAMERINI, AND S.P. JAMES

100 Effect of Enteric Pacing on Intestinal Motility and Hormone Secretion in Dogs With Short Bowel

S.B. REISER, V. SCHUSDZIARRA, E. BOLLSCHWEILER,

A.H. HÖLSCHER, AND J.R. SIEWERT

107 Scintigraphic Measurement of Regional Gut Transit in Idiopathic Constipation

T. Stivland, M. Camilleri, M. Vassallo, M. Proano, D. Rath, M. Brown, G. Thomforde, J. Pemberton, and S. Phillips

116 Lipase and Pepsin Activity in the Gastric Mucosa of Infants, Children, and Adults

J. DiPalma, C. Kirk, M. Hamosh, A.R. Colon, S.B. Benjamin, AND P. HAMOSH
122 Epidemiology of Inflammatory Bowel Disease Among U.S. Military Veterans

A. SONNENBERG AND I.H. WASSERMAN

131 Basophil-Bound and Serum Immunoglobulin E Directed Against Helicobacter pylori in Patients With Chronic Gastritis

A. Aceti, D. Celestino, M. Caferro, V. Casale, F. Citarda, E.M. Conti, A. Grassi, A. Grilli, A. Pennica, F. Sciarretta, O. LeRI, F. AMEgLio, AND A. SEbASTIANI

138 Pharmacokinetics of Oral and Intravenous Omeprazole in Patients With the Zollinger-Ellison Syndrome R. Vinayek, M. Amantea, P.N. Maton, H. Frucht, J.D. GARDNER, AND R.T. JENSEN

148 Long-Term Prognosis After Partial Gastrectomy for Benign Conditions

A.C. Tersmette, G.J.A. Offerhaus, F.M. Giardiello, R. Brand, K.W.F. TERSMETTE, G.N.J. TYTGAT, AND J.P. VANDENBROUCKE

154 Genetic Characterization of the APC Locus Involved in Familial Adenomatous Polyposis

S. Olschwang, B. Weiffenbach, P. Laurent-Puig, T. Melot,

A. Vassal, K. Fallo, R.J. Salmon, R. Parc, L. Strong,

Y. NAKAMURA, L. HERRERA, AND G. THOMAS

161 Induction of Heat Shock Proteins and Their Implication in Protection Against Ethanol-Induced Damage in Cultured Guinea Pig Gastric Mucosal Cells

K. Nakamura, K. Rokutan, N. Marul, A. Aolke, and K. Kawal

167 Positive Serum Antibody and Negative Tissue Staining for Helicobacter pylori in Subjects With Atrophic Body Gastritis

W.E. KARNES, JR., I.M. SAMLOFF, M. SiURAlA, M. KeKKI, P. SIPPONEN, S.W.R. KIM, AND J.H. WALSH

175 Reproducibility of Measurements of Trace Gas Concentrations in Expired Air A. STROCCHI, C. Ellis, AND M.D. LEVITT

\section{LIVER, PANCREAS, AND BILIARY TRACT}

180 Increased Paracellular Permeability in Intrahepatic Cholestasis Induced by Carmustine (BCNU) in Rats H. KRELL, H. FROMM, AND R.E. LARSON

189 Cost-Effectiveness of Extracorporeal Shock-Wave Lithotripsy Versus Cholecystectomy for Symptomatic Gallstones

E.B. BASS, E.P. SteinBerg, H.A. PitT, G.P. SABA, K.D. Lillemoe, D.R. KaFONEK, T.R. GadaCZ, T.A. GoRdON, AND G.F. ANDERSON

200 Distribution of the VLA Family of Integrins in Normal and Pathological Human Liver Tissue R. VOLPES, J.J. VAN DEN OORD, AND V.J. DESMET

207 The Bentiromide Test Using Plasma $p$-Aminobenzoic Acid for Diagnosing Pancreatic Insufficiency in Young Children D. LAUfer, G. Cleghorn, G. ForstNer, L. Ellis, G. KOREN, AND P. DURIE

214 Factors Affecting the Measurement of Cholesterol Nucleation in Human Gallbladder and Duodenal Bile J.W. MARKS, P. BROOMFIELD, G.G. BONORRIS, AND L.J. SCHOENFIELD 
220 Secretagogue Response of Azaserine-Induced Rat Pancreatic Acinar Tumors in Vivo

K.-H. HeRZIG, W. CREUTZFELdT, AND U.R. FÖlSCH

228 Impaired Hepatic Handling and Processing of Lysophosphatidylcholine in Rats With Liver Cirrhosis M. Angelico, D. Alvaro, A. Cantafora, R. Masella, E. Gaudio, C. Gandin, S.G. Corradini, F. Ariosto, O. Riggio, AND L. CAPOCACCIA

\section{CASE REPORTS}

238 Growth in Adulthood After Liver Transplantation for Glycogen Storage Disease Type I

B.S. KiRSCHNER, A.L. BAKER, AND F.K. THORP

242 Development of Sustained Achlorhydria in a Patient With the Zollinger-Ellison Syndrome Treated With Omeprazole J.L. GRifFITH, O.W. CuMmings, AND B.I. HiRSCHOWITZ

247 Cytomegalovirus Infection of the Appendix in a Patient With the Acquired Immunodeficiency Syndrome S. VAlerdiz-CaSASOla AND F.J. PARDO-Mindan

250 Ursodeoxycholic Acid for the Treatment of Home Parenteral Nutrition-Associated Cholestasis

K.D. LINDOR AND J. BURNES

\section{CLINICAL CHALLENGES}

254 Exacerbation of Ulcerative Colitis D.J. HeRmens and P.B. Miner, JR.

\section{SELECTED SUMMARIES}

263 Treatment of Bleeding Arteriovenous Malformations With Oral Contraceptives: Safe Sex?
264 How Enterocytes Stick and What They Stick To

266 Superficial Esophageal Carcinoma: Will Early Detection Help?

267 Evidence for a Direct Hepatoprotective Action of Ursodeoxycholic Acid in Primary Human Hepatocytes

268 Toward a Treatment for Anorexia and Cachexia in Patients With Cancer

\section{BOOK REVIEWS}

\section{CORRESPONDENCE}

274 24-Hour Intragastric Acidity and Plasma Gastrin After Omeprazole Treatment and After Proximal Gastric Vagotomy in Duodenal Ulcer Patients

274 Persisting Benzodiazepine Metabolites Responsible for the Reaction to the Benzodiazepine Antagonist Flumazenil in Patients With Hepatic Encephalopathy

275 Treatment of Cholesterol Gallstone Patients With Ursodeoxycholic Acid

276 'Abstract Creep' in GASTROENTEROLOGY

276 Pancreatic Exocrine Secretion in Acute Experimental Pancreatitis

278 Efficacy of Dextran-70 As a Substitute for Albumin

280 Calcium Carbonate Solubility in Human Common Duct Bile: Calcium Carbonate Precipitation in Gallstones

281 Acute Necrotizing Esophagitis: Another Case

283 NOTICES

NO. 2, AUGUST 1991

285 This Month in GASTROENTEROLOGY

\section{ALIMENTARY TRACT}

287 The Parietal Cell Autoantibodies Recognized in Neonatal Thymectomy-Induced Murine Gastritis Are the $\alpha$ and $\beta$ Subunits of the Gastric Proton Pump

C.M. Jones, J.M. CALlaghan, P.A. GleEson, Y. MoRI,

T. MASUDA, AND B.-H. TOH

295 Microvascular Permeability Increases Early in the Course of Acid-Induced Esophageal Injury

F.G. ZiJlstra, T.T. HyNNA-LIEPERT, P.K. DindA, I.T. BECK, AND W.G. PATERSON

303 Establishment and Characterization of a Human Carcinoid in Nude Mice and Effect of Various Agents on Tumor Growth

B.M. EvERS, C.M. TOWNSEND, JR., J.R. UpP, E. AlLEN,

S.C. Hurlbut, S.W. Kim, S. Rajaraman, P. Singh, J.C. Reubi, AND J.C. THOMPSON

312 Posttranslational Cleavage of Rat Intestinal Lactase Occurs at the Luminal Side of the Brush Border Membrane K.-Y. YeH, M. YEH, P.-C. PAN, AND P.R. HOLT
319 Effects of Vibrio cholerae Recombinant Strains on Rabbit Ileum In Vivo C.D. Lind, R.H. DAvis, R.L. GUERRANT, J.B. KAPER, AND J.R. MATHIAS

325 Effect of Neuropeptide $Y$ on Jejunal Water and Ion Transport in Humans

U. Holzer-Petsche, W. Petritsch, T. Hinterleitner, A. Eherer. G. SPERK, AND G.J. KREJS

331 Mechanism of Short-Chain Fatty Acid Uptake by Apical Membrane Vesicles of Rat Distal Colon N. MASCOLO, V.M. RAJENDRAN, AND H.J. BindER

339 Developmental Characteristics of the Kitten Antrum A.C. HILLEMEIER, K.N. BitAR, AND P. BIANCANI

344 Abnormal Esophageal Motility B.T. Massey, W.J. Dodds, W.J. Hogan, J.G. Brasseur, AND J.F. HELM

355 Regional Esophageal Distribution and Clearance of Refluxed Gastric Acid

R. SHAKER, W.J. DODdS, J.F. HELM, M.K. KERN, AND W.J. HOGAN

360 Intestinal Absorption of Fructose in the Rat T. FUjISAWA, J. Riby, AND N. KRETCHMER 
368 Long-Term Survival Analysis in Hereditary Hemochromatosis P.C. AdAMS, M. SPEECHLEY, AND A.E. KeRTESZ

373 Variation of Muscle Tone in the Human Colon C.J. Steadman, S.F. Phillips, M. Camilleri, A.C. Haddad, AND R.B. HANSON

382 Premicellar Taurocholate Enhances Ferrous Iron Uptake From All Regions of Rat Small Intestine A.J. SANYAL, M.L. ShifFMAn, J.I. HiRSCH, AND E.W. MOORE

390 T-Lymphocyte Dysfunctions Occurring Together With Apical Gut Epithelial Cell Autoantibodies J.M. Martín-Villa, J.R. Regueiro, D. DE JuAn, P. PÉrez-Aciego, M. Pérez Blas, J. Manzanares, G. Varela, AND A. ARNAIZ-VILLENA

398 Ion Transport Abnormalities in Rectal Suction Biopsies From Children With Cystic Fibrosis H.J. VEEZE, M. SiNAASAPPEL, J. BIJMAN, J. BOUQUET, AND H.R. DE JONGE

404 Aspirin Induces Morphological Transformation to the Secretory State in Isolated Rabbit Parietal Cells U.K. MURTHY AND R.A. LEVINE

410 Circadian Rhythm of Cellular Proliferation in the Human Rectal Mucosa

K.N. BUCHI, J.G. MOORE, W.J.M. HRUSHESKY, R.B. SOTHERN, AND N.H. RUBIN

416 Sensory Neurons Signal for an Increase in Rat Gastric Mucosal Blood Flow in the Face of Pending Acid Injury P. HOLZER, E.H. LIVINGSTON, AND P.H. GuTH

424 Presence of Atrial Natriuretic Factor Prohormone in Enterochromaffin Cells of the Human Large Intestine A.L. Gerbes, W. Nathrath, M. Cantin, and H. Denecke

430 Increased $\mathrm{Na}^{+} \cdot \mathrm{H}^{+}$Exchange in Jejunal Brush Border Membrane Vesicles of Spontaneously Hypertensive Rats S. ACRA AND F.K. GHISHAN

437 Helicobacter pylori Infection Induces Antibodies CrossReacting With Human Gastric Mucosa R. Negrini, L. Lisato, I. Zanella, L. Cavazzini, S. Gullini, V. Villanacci, C. Poiesi, A. Albertini, and S. Ghielmi

\section{LIVER, PANCREAS, AND BILIARY TRACT}

446 Activation of Mast Cells by Bile Acids

R.G. QUist, H.-T. TON-Nu, J. LILLIENAU, A.F. HOFMANN, AND K.E. BARRETT

457 Cell Type-Dependent Effect of Phospholipid and Cholesterol on Bile Salt Cytotoxicity

A.L.M. Velardi, A.K. Groen, R.P.J.O. ElFERINK, R. van DER MEer, G. Palasciano, and G.N.J. Tytgat

465 Pancreatic Lesions in the von Hippel-Lindau Syndrome H.P.H. NeumanN, E. Dinkel, H. BRAMBS, B. WimMer, H. Friedburg, B. Volk, G. Sigmund, P. Riegler, K. HaAg, P. SCHOLLMEYER, AND O.D. WIESTLER

472 The Stomach in Liver Cirrhosis S. Vigneri, R. Termini, A. Piraino, A. Scialabba, G. Pisciotta, AND N. FONTANA

479 Bile Evacuation Induced by Hypothalamic Stimulation in Dogs

N. FuRUKaWA AND H. OKADA

490 Comparative Evaluation of Chenodeoxycholic and Ursodeoxycholic Acids in Obese Patients G. Mazzella, F. BAzzoli, D. Festi, M. RonChI, R. Aldini, A. Roda, B. Grigolo, P. Simoni, N. Villanova, and E. Roda
497 Comparison of 1 or $3 \mathrm{MU}$ of Interferon Alfa-2b and Placebo in Patients With Chronic Non-A, Non-B Hepatitis X. Causse, H. Godinot, M. Chevaluier, P. Chossegros, F. ZOULIM, D. OUZAN, J.-P. HEYraud, T. FonTANGES, J. Albrecht, C. Meschievitz, AND C. TREPo

503 Role of Cholecystokinin in the Regulation of Gastric Emptying and Pancreatic Enzyme Secretion in Humans M. Fried, U. ERLACHER, W. SCHWIZER, C. LÖCHNER, J. KOERFER, C. BEglinger, J.B. JANSEN, C.B. LAMERS, F. HARDER, A. Bischof-Delaloye, G.A. Stalder, AND L. Rovati

512 Intraductal Mucin-Hypersecreting Neoplasms of the Pancreas

F. Rickaert, M. Cremer, J. Devière, L. Tavares, J.P. LAMBILLIOTTE, S. SCHRÖDER, D. WURBS, AND G. KLÖPPEL

\section{CASE REPORTS}

520 Intestinal and Hepatic Apolipoprotein B Gene Expression in Abetalipoproteinemia

D.D. BLACK, R.V. HAY, P.L. ROHWER-NUTTER, H. ElLINAS, J.K. STEPHENS, H. SHERMAN, B.-B. TENG, P.F. WhITINGTON, AND N.O. DAVIDSON

529 Rhabdomyolysis and Cutaneous Necrosis Following Intravenous Vasopressin Infusion

D. MoReno-SÁnChez, B. Casis, A. Martín, P. ORTiz,

G. Castellano, M.T. MuÑz, F. VanaClocha, AND J.A. SOLÍs-HERRUZO

533 Idiopathic Myointimal Hyperplasia of Mesenteric Veins R.M. GENTA AND R.C. HAGGiTt

\section{BRIEF REPORTS}

540 Metabolism of Trinitrobenzene Sulfonic Acid by the Rat Colon Produces Reactive Oxygen Species M.B. Grisham, C. Volkmer, P. TSO, and T. Yamada

\section{SPECIAL REPORTS AND REVIEWS}

548 Reports From the NIH DDDN F.A. HaMilton AND J.H. HoOfNagle

\section{SELECTED SUMMARIES}

550 Antibiotic Prophylaxis for Prevention of Spontaneous Bacterial Peritonitis?

552 Nitroglycerin in the Treatment of Portal Hypertension

553 Endoscopic Management of Gastric Outlet Obstruction

554 At Long Last-The Histamine $\mathrm{H}_{2}$-Receptor Gene Is Cloned

555 NSAID-Induced Gastroduodenal Injury: What's the Score?

\section{BOOK REVIEWS}

\section{TRAINING AND EDUCATION IN GASTROENTEROLOGY}

560 List of Available Training Programs

\section{CORRESPONDENCE}

589 Ethanol Stimulates Pepsinogen Release From Isolated Guinea Pig Chief Cells

590 Hemodynamic Events in a Prospective Randomized Trial of Propranolol Versus Placebo in the Prevention of a First Variceal Hemorrhage 
592 The Possible Role of Phospholipase in Gallstone Pathogenesis

593 Host Response to Mycobacterial Infection in the Alcoholic Rat

594 Tumor Necrosis Factor $\alpha$ in the Pathophysiology of Necrotizing Enterocolitis
594 Fasting and Postprandial Residual Gallbladder Volumes

595 CORRECTION

596 NOTICES

NO. 3, SEPTEMBER 1991

597 This Month in GASTROENTEROLOGY

\section{ALIMENTARY TRACT}

599 The Cephalic and Gastric Phases of Gastric Secretion During $\mathrm{H}_{2}$-Antagonist Treatment

H.S. MERKI, C.H. WILDER-SMITH, R.P. WALT, AND F. HALTER

607 Effect of Intrathoracic Pressure on Plasma Arginine Vasopressin Levels

J.A. Solis-Herruzo, D. Moreno, A. Gonzalez, L. Larrodera,

G. Castellano, J. Gutierrez, and A. Gozalo

618 Expression of Sucrase-Isomaltase and Dipeptidylpeptidase IV in Human Small Intestine and Colon

J.P. Gorvel, A. Ferrero, L. Chambraud, A. Rigal, J. Bonicel, AND S. MAROUX

626 Intestinal Obstruction During Shigellosis: Incidence, Clinical Features, Risk Factors, and Outcome

M.L. BENNISH, A.K. AZAD, AND D. YOUSEFZADEH

635 Sulindac Causes Regression of Rectal Polyps in Familial Adenomatous Polyposis

D. Labayle, D. Fischer, P. Vielh, F. Drouhin, A. Pariente,

C. Bories, O. Duhamel, M. Trousset, and P. Attali

640 Radioautographic Localization of Epidermal Growth Factor Receptors in Human Fetal Gut

D. MÉNARD AND P. POTHIER

650 Observations on a Proposed Measure of Genotoxicity in Rat Gastric Mucosa

S. HOLT, Z. ZHAO-HUA, AND R.E. POWERS

657 Hypertrophic Smooth Muscle in the Partially Obstructed Opossum Esophagus

J.L. Conklin, C. Du, K. Schulze-Delrieu, and S. Shirazi

664 Trichinella spiralis Infection Alters Small Bowel Motor Activity in the Fed State

V.E. COWLES AND S.K. SARNA

670 Immunohistochemical Characterization, Distribution, and Ultrastructure of Lymphocytes Bearing T-Cell Receptor $\gamma / \delta$ in Inflammatory Bowel Disease

K. FuKushima, T. Masuda, H. Ohtani, I. SASAKI, Y. Funayama, S. MATSUNO, AND H. NAGURA

679 Quality of Life After Proctocolectomy L.W. KÖHLER, J.H. PEMBERTON, A.R. ZinSMEISTER, AND K.A. KELLY

685 Acute Abdomen as the First Presentation of Pseudomembranous Colitis G. TRIADAFILOPOULOS AND A.E. HALLSTONE
692 Isolation, Characterization, and Attachment of Rabbit Distal Colon Epithelial Cells

R.V. BENYA, L.N. SCHMidT, J. SAHI, T.J. LAYDEN, AND M.C. RAO

703 Mechanism for the Gastrokinetic Action of Domperidone T. Takahashi, S. Kurosawa, J.W. Wiley, and C. OWYanG

711 Cancer Incidence Following Subtotal Gastrectomy G.N. Stemmermann, A.M.Y. Nomura, and P.-H. ChyOU

716 Rat Enterocyte Injury by Oxygen-Dependent Processes S.S. BAKER AND C.L. CAMPBELL

721 Fecal Carriage of Streptococcus bovis and Colorectal Adenomas

R. Dubrow, S. EDberg, E. Wikfors, D. CAllan, F. Troncale, R. VENDER, M. BRAND, AND R. YAPP

726 Antitumor Effect of Synthetic Derivatives of Lipid A in an Experimental Model of Colon Cancer in the Rat J.-F. JeANNin, N. ONIER, P. LAGAdec, N. von Jeney, P. Stütz, AND E. LIEHL

734 Neural and Hormonal Mechanisms Mediate the Enterogastric Reflex: A Study in Intestinal Transplants in Rats

S.L. ORLOFF, N.W. BunNETT, H. WONG, J.H. WAL.SH, AND H.T. DEBAS

743 Classic and Vigorous Achalasia: A Comparison of Manometric, Radiographic, and Clinical Findings S.P. GoldenberG, M. BurRell, G.G. FetTE, C. Vos, AND M. TRAUBE

749 Apolipoprotein Synthesis in Normal and Abetalipoproteinemic Intestinal Mucosa R.M. GlickMAN, J.N. GLICKMAN, A. MAGUN, AND M. BRIN

756 Nonsalicylate Nonsteroidal Antiinflammatory Drugs Augment Prestimulated Acid Secretion in Rabbit Parietal Cells

R.A. LEVINE, J. NANDI, AND R.L. KING

\section{LIVER, PANCREAS, AND BILIARY TRACT}

766 Detection and Partial Sequencing of Hepatitis C Virus RNA in the Liver

K. Hosoda, O. Yokosuka, M. Omata, N. Kato, and M. Ohto

772 The Effects of Benzodiazepine-Receptor Antagonists and Partial Inverse Agonists on Acute Hepatic Encephalopathy in the Rat

D.K. BOSMAN, C.A.C.G. vaN DEN BUIS, J.G. DE HAAN,

M.A.W. MAas, AND R.A.F.M. ChamUlEaU 
782 Elevation of Serum Interleukin-6 Concentration Precedes Acute-Phase Response and Reflects Severity in Acute Pancreatitis

H.-G. Leser, V. Gross, C. Scheibenbogen, A. Heinisch, R. Salm, M. LAUSEN, K. RÜCKAUER, R. ANDREESEN, E.H. FARTHMANN, AND J. SCHÖLMERICH

786 Acalculous Biliary Pain: Cholecystectomy Alleviates Symptoms in Patients With Abnormal Cholescintigraphy L. YAP, A.G. WYCHERLEY, A.D. MORPHETT, AND J. TOOULI

794 Noninvasive Measurement of Liver Regeneration With Positron Emission Tomography and $\left[2 \cdot{ }^{11} \mathrm{C}\right]$ Thymidine T. VANDER Borght, L. LAMBotTE, S. PAUWELS, D. LABAR, C. BECKers, AND C. Dive

800 The Effects of Chronic Endoscopic Variceal Sclerotherapy on Portal Pressure in Cirrhotics J. KoRULA AND P. RALLS

806 Chronic Dietary Iron Overload in Rats Results in Impaired Calcium Sequestration by Hepatic Mitochondria and Microsomes

R.S. BRITTON, R. O’NEILL, B.R. BACON

812 Inhibition of Prostaglandin Synthesis Fails to Prevent Gallbladder Mucin Hypersecretion in the Cholesterol-Fed Prairie Dog D.P. O'LEARY, W.W. LAMORTE, T.E. SCOTT, M.L. BOOKER, AND J. STEVENSON

821 Microanalysis of Bile Acid Composition in Intrahepatic Calculi and Its Etiological Significance

J. Shoda, N. Tanaka, Y. Matsuzaki, A. Honda, T. Osuga,

S. Shigematsu, AND H. MiYAZAKI

\section{CASE REPORTS}

831 Clonorchis-Associated Cholangiocarcinoma: A Report of Two Cases With Unusual Manifestations F.V. ONA AND J.N.T. DYTOC

\section{BRIEF REPORTS}

840 Interferon-Induced Chronic Active Hepatitis? M.O. Silva, K.R. REDDY, L.J. JefFers, M. HiLl, AND E.R. SChifF

\section{SPECIAL REPORTS AND REVIEWS}

843 A Reappraisal of the Magnitude and Implications of the Intestinal Unstirred Layer A. STROCCHI AND M.D. LEVITT

\section{CLINICAL CHALLENGES}

848 Hypoproteinemia, Anemia, and Failure to Thrive in an Infant

J.E. BINES AND E.J. ISRAEL

\section{EDITORIALS}

857 Lessons From Experimental Cholelithiasis: Gallbladder and Mucosa, Nonsteroidal Antiinflammatory Drugs, and Gallstones

S.P. LEE

\section{SELECTED SUMMARIES}

861 One More Reason for Weight Loss in Patients With AIDS

862 Hepatitis B and Human Immunodeficiency Virus: Double Trouble

863 Acute and Chronic Giant Cell Hepatitis: A Paramyxovirus Infection?

864 Peliosis Hepatis: Old Disease, New Cause

866 A Biopsychosocial Model for Functional Dyspepsia

869 BOOK REVIEWS

\section{CORRESPONDENCE}

871 Vegetable Peroxidase Is Denatured by Gastric Acid

871 Estimation of Risk of Transmission of Non-A, Non-B Hepatitis by Needlestick Injury

872 Free Radical Scavengers and Inflammatory Bowel Disease

872 Role of Parenteral Nutrition in Crohn's Colitis

874 Treatment of Intestinal Cryptosporidiosis With Zidovudine and SMS 201-995, a Somatostatin Analog

874 Somatostatin and Acute Variceal Hemorrhage

875 Prevalence of Columnar-Lined (Barrett's) Esophagus

876 Asthmatics' Gastroesophageal Reflux With or Without Bronchodilator Therapy

878 NOTICES

NO. 4, OCTOBER 1991

879 This Month in GASTROENTEROLOGY

\section{ALIMENTARY TRACT}

881 Comparison of Enteral Nutrition and Drug Treatment in Active Crohn's Disease

H. LOCHS, H.J. STEINHARDT, B. KLAUS-WENTZ, M. ZEITZ,

H. VOgelsang, H. SOMMER, W.E. Fleig, P. BAUER,

J. SCHIRRMEISTER, AND H. MALCHOW
889 The Effect of Histamine $\mathrm{H}_{2}$-Receptor Blockade on Bismuth Absorption From Three Ulcer-Healing Compounds C.U. Nwokolo, E.J. PrewetT, A.M. SAwYerR, M. Hudson, AND R.E. POUNDER

895 Electrolyte Transport in Piglets Infected With Transmissible Gastroenteritis Virus F.R. HOMAIDAN, A. TORRES, M. DONOWITZ, AND G.W.G. SHARP

902 Comparative Evaluation of Acid- and Bile-Induced Damage to Pedicled Jejunal or Colonic Segments in the Rat G.B. Ratto, P. Romano, AND D. Zaccheo 
910 Mechanism of Inhibitory Action of Prostaglandins on the Growth of Human Gastric Carcinoma Cell Line KATO III A. Nakamura, T. Yamatani, T. Fujita, and T. Chiba

919 Comparative Evaluation of Carcinoembryonic Antigen, Secretory Component, and Mucins in Index and Metachronous Adenomas of the Colorectum G. Griffioen, F.T. Bosman, H.W. Verspaget, K.F.M. Sier, I. BIEMOND, AND C.B.H.W. LAMERS

927 Epidemiology of Colonic Symptoms and the Irritable Bowel Syndrome

N.J. TAlley, A.R. ZinSmeister, C. VAN DyKe, AND L.J. MELTON III

935 Action of Beer and Its Ingredients on Gastric Acid Secretion and Release of Gastrin in Humans M.V. SINGER, S. TEYSSEN, AND V.E. EYSSELEIN

943 Omeprazole Treatment Does Not Affect the Metabolism of Caffeine

T. Andersson, R. Bergstrand, C. Cederberg, S. Eriksson, P.-O. LAGERSTRÖM, AND I. SKANBERG

948 Tolerance During 5 Months of Dosing With Ranitidine, 150 mg Nightly: A Placebo-Controlled, Double-Blind Study C.U. NWOKOLO, E.J. PrewetT, A.M. SAWYERR, M. HudSON, S. LIM, AND R.E. POUNDER

954 Role of Capsaicin-Sensitive Afferent Neurons in Alkaline Secretory Response to Luminal Acid in the Rat Duodenum K. TaKeuchi, J. Matsumoto, K. Ueshima, and S. OKabe

962 Reverse-Perfused Sleeve: An Improved Device for Measurement of Sphincteric Function of the Crural Diaphragm

B. SIVRI AND R.K. MITTAL

970 Opioids Inhibit Neuromuscular Transmission in Circular Muscle of Human and Baboon Jejunum

A.J. BAUER, M.G. SARR, AND J.H. SZURSZEWSKI

977 Effect of Age on Gastric Acid Secretion and Serum Gastrin Concentrations in Healthy Men and Women

M. GOldSCHMIEDT, C.C. BARNETT, B.E. SChWARZ, W.E. KaRNES, J.S. REDFERN, AND M. FELDMAN

991 Enterogastric Reflux After Various Types of Antiulcer Gastric Surgery: Quantitation by ${ }^{99 \mathrm{~m}} \mathrm{Tc}-\mathrm{HIDA}$ Scintigraphy E. Xynos, J.S. Vassilakis, A. Fountos, G. Pechlivanides, AND N. KARKAVITSAS

999 The Origin of Symptoms on the Brain-Gut Axis in Functional Dyspepsia

F. Mearin, M. CuCAla, F. Azpiroz, ANd J.-R. Malagelada

1007 Electroencephalogram Patterns During Sleep Reflux in Infants

J.M. SONDHEIMER AND E. HODDES

1012 In Vivo Evidence of Altered Chloride but Not Potassium Secretion in Cystic Fibrosis Rectal Mucosa

J.L. Goldstein, A.B. SHAPIRO, M.C. RAO, AND T.J. LAYDEN

1020 Increased Activation of Isolated Intestinal Lamina Propria Mononuclear Cells in Inflammatory Bowel Disease S. SCHREIBER, R.P. MACDERMOTt, A. RAEDLER, R. PinNaU, M.J. BERTOVICH, AND G.S. NASH

1031 Effects of Diazepam and Ro 15-1788 on Duodenal Bicarbonate Secretion in the Rat B. SÄFSTEN, G. JEDSTEDT, AND G. FLEMSTRÖM
1039 Reversal of Protein-Bound Vitamin $B_{12}$ Malabsorption With Antibiotics in Atrophic Gastritis

P.M. SUTER, B.B. GOLNER, B.R. Goldin, F.D. MORROW, AND R.M. RUSSELL

1046 Short-Chain Glucose Polymer and Anthracene-9-carboxylic Acid Inhibit Water and Electrolyte Secretion Induced by Dibutyryl Cyclic AMP in the Small Intestine G.H. Rabbani, R.-B. Lu, K. Horvath, and E. Lebenthal

\section{LIVER, PANCREAS, AND BILIARY TRACT}

1054 Light and Electron Microscopy of Neuropeptide YContaining Nerves in Human Liver, Gallbladder, and Pancreas W.-G. Ding, M. Fujimura, A. Mori, I. TOOyama, AND H. KIMURA

1060 Ornipressin in the Treatment of Functional Renal Failure in Decompensated Liver Cirrhosis

K. Lenz, H. HörtNAGL, W. DrumL, H. ReITHER, R. SCHMiD

B. SchneEweiss, A. LagGner, G. Grimm, and A.L. Gerbes

1068 Complications of Endoscopic Sphincterotomy S. SHERMAn, T.A. RufFolo, R.H. HAwES, AND G.A. LEHMAN

1076 Defective Fc Receptor-Mediated Clearance in Patients With Primary Biliary Cirrhosis K. NILSSON EKDAHL, L. LÖÖF, A. NYBERG, U.R. NILSSON, AND B. NILSSON

1083 Azathioprine Treatment Increases Hepatocyte Turnover N. ARBER, G. ZAJICEK, J. NORDENBERG, AND Y. SidI

1087 Prophylactic Sclerotherapy in High-Risk Cirrhotics Selected by Endoscopic Criteria

R. DE Franchis, M. Primignani, P.G. ARcidiacono, P.M. RizZi, P. Vitagliano, M.C. Vazzoler, R. ArCidiacono, A. Rossi,

A. Zambelli, F. Cosfentino, G. Calettl, S. Brunati,

G. Battaglia, and G. Gerunda

$1094 \mathrm{An} \mathrm{Na}^{+}$-Dependent and an $\mathrm{Na}^{+}$-Independent System for Glutamine Transport in Rat Liver Basolateral Membrane Vesicles

H.M. SAID, D. HOLLANDER, AND S. KHORCHID

1102 Glucocorticoids Stimulate Ornithine Decarboxylase Gene Expression in Pancreatic AR42J Cells S. RosEwiCZ AND C.D. LOGSDON

1109 Aspirin Does Not Inhibit Cholesterol Cholelithiasis in Two Established Animal Models B.I. COHEN, E.H. MosBaCh, N. AyYAD, M. Yoshil, AND C.K. MCSHERRY

\section{BRIEF REPORTS}

1117 Hepatitis C Virus Antibodies in Acute Icteric and Chronic Non-A, Non-B Hepatitis

J.G. McHutchison, G. Kuo, M. Houghton, Q.-L. Сhoо, AND A.G. REDEKER

\section{CLINICAL CHALLENGES}

1120 Fecal Incontinence in a 39-Year-Old Man R.J. MAY

\section{EDITORIALS}

1127 Enteral Feeding Versus Drug Therapy in Crohn's Disease: A Continuing Story J.W. SINGLETON 


\section{SELECTED SUMMARIES}

1129 Treatment of Severe Postgastrectomy Dumping With a Long-Acting Somatostatin Analog: Is Effective Management Finally Available?

1130 Sulfasalazine vs. Steroids in Crohn's Disease: David vs. Goliath?

1131 Recurrent Hepatitis B in Liver Transplant Recipients-No Easy Answers

1133 Sporadic vs. Posttransfusion Hepatitis C: Why the Differences?

1134 Bidirectional Communication Between Mast Cells and Nerves Controls Intestinal Secretion

\section{BOOK REVIEWS}

\section{CORRESPONDENCE}

1139 Concentration in Pancreatic Juice of Lithostathine

1140 Pathogenesis and Treatment of Rotavirus Diarrhea

1141 Prevalence of Spontaneous Hepatofugal Portal Flow in Liver Cirrhosis

1142 Enteric Neuronal Autoantibodies in Pseudoobstruction With Small-Cell Lung Carcinoma

1144 Hyperplastic Polyps and Risk of Adenomas

1146 NOTICES

NO. 5, NOVEMBER 1991

1147 This Month in GASTROENTEROLOGY

\section{ALIMENTARY TRACT}

1149 A Critical Analysis, With Appropriate Controls, of Gastric Acid and Pepsin Secretion in Clinical Esophagitis B.I. HIRSCHOWITZ

1159 Primary B-Cell Gastric Lymphoma: A Clinicopathological Study of 145 Patients

S.B. Cogliatti, U. SCHMid, U. SChUMaChER, F. ECKERT, M.-L. HANSMANN, J. HedDerich, H. TAKAHASHI, AND K. LENNERT

1171 Value of Transrectal Ultrasonography in Crohn's Disease M.J. Van Outryve, P.A. Pelckmans, P.P. Michielsen, AND Y.M. VAN MAERCKE

$1178 \gamma$-Aminobutyric Acid Localization and Function as Modulator of Cholinergic Neurotransmission in Rat Antral Mucosal/Submucosal Fragments

R.F. HARTY, M.G. BOHARSKI, G.S. BOCHNA, T.A. CARR, P.E. EAGAN, M. RINGS, D.C. LASSITER, M.P. POUR, D.F. SCHAFER, AND R.S. MARKIN

1187 Histological Maturity of Healed Duodenal Ulcers and Ulcer Recurrence After Treatment With Colloidal Bismuth Subcitrate or Cimetidine

S. PAN, C.-H. LIAO, G.-S. LIEN, AND S.-H. CHEN

1192 Portal Colopathy: Prospective Study of Colonoscopy in Patients With Portal Hypertension R.A. KOZAREK, V.A. BOTOMAN, J.E. BREDFELDT, J.M. ROACH, D.J. Patterson, AND T.J. Ball

1198 Distribution of Aneuploid Cell Populations in Ulcerative Colitis With Dysplasia or Cancer D.S. LEVINE, P.S. RabinOvitCh, R.C. HAGGitT, P.L. BlounT, P.J. DEAN, C.E. Rubin, AND B.J. REID

1211 Calcitonin Gene-Related Peptide and Substance P Decrease in the Rabbit Colon During Colitis V.E. Eysselein, M. REinShagen, F. Cominelli, C. Sternini, W. Davis, A. Patel, C.C. Nast, D. Bernstein, K. Anderson, H. KHAN, AND W.J. SNAPE, JR.

1220 Mechanisms of Acid Injury to Rabbit Esophageal Epithelium

N.A. TOBEY AND R.C. ORLANDO
1229 Prostaglandins and the Colonic Epithelium R.A. Goodlad, N. Mandir, S. Levin, J.L. Allen, AND N.A. WRIGHT

1235 Morphometry and Cell Proliferation in Endoscopic Biopsies: Evaluation of a Technique R.A. Goodlad, S. Levi, C.Y. LeE, N. Mandir, H. Hodgson, AND N.A. WRIGHT

1242 The Role of Vasopressin in the Pathogenesis of EthanolInduced Gastric Hemorrhagic Erosions in Rats F. LásZló, G. KarácSONY, E. SZabó, J. LáNG, L. BalásPiri AND F.A. LÁSZLó

1249 Central and Peripheral Control of Postprandial Pyloric Motility by Endogenous Opiates and Cholecystokinin in Dogs

Y. LOPEZ, J. FIORAMONTI, AND L. BUENO

1256 Peptidergic Innervation of the Human Esophageal Smooth Muscle

C. Singaram, A. Sengupta, D.J. Sugarbaker, and R.K. Goyal

1264 Changes in the Structure and Regeneration Mode of the Rat Small Intestinal Mucosa Following Benzalkonium Chloride Treatment

G.E. HOLLE

1274 Different Fibers Have Different Regional Effects on Luminal Contents of Rat Colon

A. MCInTYRE, G.P. Young, T. TARANTO, P.R. GiBSON, AND P.B. WARD

1282 Inversion of the Slow-Wave Frequency Gradient in Symptomatic Patients With Roux-en-Y Anastomoses G. Vantrappen, G. Coremans, J. Janssens, A. Mantides, AND F. VANDEN BORRE

1289 Colonic Motility and Transit in Health and Ulcerative Colitis

S.N. Reddy, G. Bazzocchi, S. Chan, K. AKashi, J. Villanueva-Meyer, G. YanNi, I. Mena, And W.J. SnAPE, JR.

1298 Effect of Eating on Colonic Motility and Transit in Patients With Functional Diarrhea

G. BAZZOCCHI, J. Ellis, J. Villanueva-MEYeR, S.N. REDDY, I. MENA, AND W.J. SNAPE, JR. 
1307 Quality of Life of Patients With Ulcerative Colitis Preoperatively and Postoperatively R.S. MCLEOD, D.N. ChuRCHILl, A.M. LOCK, S. VANDERBURGH, AND Z. COHEN

1314 Perendoscopic Manometry of the Distal Ileum and Ileocecal Junction in Humans

E. Corazziari, F. BARberani, M. Tosoni, S. Boschetto, AND A. TORSOLI

1320 Delayed Gastrointestinal Transit Times in Anorexia Nervosa and Bulimia Nervosa

N. Kamal, T. Chami, A. Andersen, F.A. Rosell, M.M. SCHUSTER, AND W.E. WHITEHEAD

\section{LIVER, PANCREAS, AND BILIARY TRACT}

1325 Ultrasonic Tissue Characterization of Chronic Liver Disease Using Cepstral Analysis

K. SUZUKI, N. HaYASHI, Y. SASAKI, M. KonO, Y. IMAI, H. FUSAMOTO, AND T. KAMADA

1332 Treatment of Primary Biliary Cirrhosis With Low-Dose Weekly Methotrexate M.M. KAPLAN AND T.A. KNOX

1339 Effect of Phospholipase C on Cholesterol Solubilization in Model Bile

N.R. PATtinson AND K.E. Willis

1345 Effectiveness of a Purified Human Hemoglobin as a Blood Substitute in the Perfused Rat Liver

H.F. Starnes, JR., A. Tewari, K. Flokas, J.C. Kosek,

D. BROWN, A.L. VAN-KESSEL, AND C.E. MONDON

1354 Abnormal Sympathetic and Renal Response to Sodium Restriction in Compensated Cirrhosis M.-A. SimóN, J. DíEz, AND J. PRIETO

1361 Lipase/Amylase Ratio V.V. Gumaste, P.B. Dave, D. Weissman, and J. Messer

1367 HLA DRw8 and Complement C4 Deficiency as Risk Factors in Primary Biliary Cirrhosis

M.P. MANNS, A. BRfmM, P.M. SC.HNEIDFr, A. NOTGHI,

G. Gerken, M. Prager-Eberle, B. Stradmann-Bellinghausen, K.-H. MEYER ZUM BÜSCHENFELDE, AND C. RITTNER

1374 Risk Factors for Septicemia Following Endoscopic Biliary Stenting

S. Motte, J. Deviere, J.-M. Dumonceau, E. Serruys, J.-P. THYS, AND M. CREMER

1382 A Shift in Balance Between Profibrinolytic and Antifibrinolytic Factors Causes Enhanced Fibrinolysis in Cirrhosis

F.W.G. LeEbeEK, C. KLuft, E.A.R. KNot, M.P.M. De MAAT, AND J.H.P. WILSON

1391 Lithotripsy of Gallstones by Means of a Quality-Switched Giant-Pulse Neodymium:Yttrium-Aluminum-Garnet Laser J. Hochberger, E. Gruber, P. WirTZ, U. DÜrr, A. Kolb, U. ZANGER, E.G. HAHN, AND C. ElL

1399 Portal and Biliary Phases of Enterohepatic Circulation of Corrinoids in Humans

S. El Kholty, J.-L. Gueant, L. Bressler, M. Dialali,

P. BoIsSEl, P. GERARD, AND J.-P. Nicolas

1409 Significance of Computed Tomography for Shock-Wave Therapy of Radiolucent Gallbladder Stones

C. Ell, H.T. SCHNEIDER, J. BENNinger, S. TheObaldy,

N. FRIEDEL, W. RÖDL, P. WIRTZ, AND E.G. HAHN

\section{CASE REPORTS}

1417 Postinfantile Giant Cell Hepatitis in Association With Hypereosinophilia

A. Kumar AND G.Y. MinuK

1420 Idiopathic Neonatal Iron-Storage Disease J.A. BARNARD III AND E. MANCI

\section{BRIEF REPORTS}

1428 Cholecystokinin-Mediated Ileal Electrolyte Transport in the Guinea Pig

J.F. KACHUR, S.-X. WANG, G.W. GULLIKSON, AND T.S. GAGINELLA

\section{CLINICAL CHALLENGES}

1432 Recurrent Gastrointestinal Bleeding Associated With Myelofibrosis and Diffuse Intestinal Telangiectasias S.D. FREEDMAN, R.E. DREWS, D.J. GLOTZER, D. KIM, H. GARDNER, AND S.J. GALLI

\section{EDITORIALS}

1440 Methotrexate Therapy of Primary Biliary Cirrhosis: Promising but Worrisome J.H. HoOfNaGle AND N.V. BERGASA

\section{SELECTED SUMMARIES}

1443 Pregnancy in Liver Transplant Patients-And Vice Versa

1444 The p53 Gene and Hepatocellular Carcinoma

1445 Transforming Growth Factors in Human Chronic Hepatitis and Cirrhosis: Correlations With Fibrogenesis and Hepatic Regeneration

1446 Somatostatin Therapy for AIDS Diarrhea: Muddy Waters $1448 \mathrm{H}_{2}$ Antagonists by Continuous Infusion: IV or IG?

\section{BOOK REVIEWS}

\section{CORRESPONDENCE}

1452 Functional Bowel Disease: The Role of Fructose and Sorbitol

1453 Role of Fructose-Sorbitol Malabsorption in the Irritable Bowel Syndrome

1454 Fructose Malabsorption and the Irritable Bowel Syndrome

1454 Helicobacter pylori Infection and Inflammation of the Gastric Corpus

1455 Postparacentesis Plasma Expansion Prevents Asymptomatic Laboratory Abnormalities, but Does It Have Any Impact on Morbidity or Mortality?

1457 Cancer Risk in Left-Sided Colitis

1458 Stress Ulcer Prophylaxis

1459 The Use of 6-Mercaptopurine in Adolescents With Crohn's Disease

1460 CORRECTIONS

1461 NOTICES 
NO. 6, DECEMBER 1991

1463 This Month in GASTROENTEROLOGY

\section{AMERICAN GASTROENTEROLOGICAL ASSOCIATION}

1465 Presidential Address D.H. ALPERS

1468 Presentation of the Julius Friedenwald Medal to Cyrus E. Rubin, M.D.

W.M. WEINSTEIN

\section{ALIMENTARY TRACT}

1471 Galanin Inhibition of Vasoactive Intestinal Polypeptide Release and Circular Muscle Motility in the Isolated Perfused Canine Ileum

J.-A.E.T. Fox-THRELKELD, T.J. MCDONALD, S. CiPRIS, Z. WOSKOWSKA, AND E.E. DANIEL

1477 The Minor Components of the Rat Asialoglycoprotein Receptor Are Apically Located in Neonatal Enterocytes C. Hu, E.Y. LeE, J.E. HewitT, J.U. BAENZIGER, J.-Z. Mu, K. DeSchryver-Kecskemeti, AND D.H. Alpers

1488 Gastrointestinal Motor Effects of Erythromycin in Humans S.K. SARNA, K.H. SOERGEL, T.R. KOCH, J.E. STONE, C.M. WOOD, R.P. Ryan, R.C. ARndorfer, J.H. Cavanaugh, H.N. Nellans, AND M.B. LEE

1497 Colonic Fermentation to Short-Chain Fatty Acids Is Decreased in Antibiotic-Associated Diarrhea M.R. Clausen, H. BONnÉN, M. TVEDE, AND P.B. MoRTENSEN

1505 Differential Effect on Neuropeptide Release of Different Concentrations of Hydrogen Ions on Afferent and Intrinsic Neurons of the Rat Stomach

P. Geppetti, M. Tramontana, S. Evangelista, D. Renzi, C.A. Maggi, B.M. Fusco, and E. Del Bianco

1512 High Incidence of Esophageal Motor Disorders in Consecutive Patients With Globus Sensation G. Moser, G.V. Vacariu-Granser, C. Schneider, T.-A. Abatzi, P. Pokieser, G. Stacher-JanotTa, G. GaupmanN, U. Weber, T. WENZEL, M. RODEN, AND G. STACHER

1522 Imbalance of Plasminogen Activators and Their Inhibitors in Human Colorectal Neoplasia C.F.M. SieR, H.W. Verspaget, G. Griffioen, J.H. Verheijen, P.H.A. QuaX, G. DoOIJEWAard, P.A.F. DE BRUIN, AND C.B.H.W. LAMERS

1529 Activation and Signaling Status of Human Lamina Propria T Lymphocytes

L. QIAO, G. SchürmanN, M. BETZleR, AND S.C. MEueR

1537 Colonic Motor Response to a Meal in Acute Colitis A.K. SETHI AND S.K. SARNA

1547 Antral Gastrin Cell Hyperfunction in Children B. AnNibale, M. Bonamico, G. Rindi, L. Villani, E. Ferrante, A. Vania, E. Solcia, and G. Delle Fave

1552 Regulation of Rat Antral Gastrin and Somatostatin Gene Expression During Starvation and After Refeeding V. Wu, K. Sumil, A. Tari, M. SumII, AND J.H. Walsh

1559 Radial and Longitudinal Asymmetry of Human Pharyngeal Pressures During Swallowing V.W. SEARs, JR., J.A. CASTELL, AND D.O. Castell
1564 Cisapride in Children With Chronic Intestinal Pseudoobstruction

C. Di Lorenzo, S.N. Reddy, J. VillanueVa-Meyer, I. MEnA, S. MARTIN, AND P.E. HYMAN

1571 Colonic Motility in Innervated and Extrinsically Denervated Loops in Dogs

C. Shibata, I. Sasaki, S. Matsuno, A. Mizumoto, and Z. Itoh

1579 Dual Effect of Trimebutine on Contractility of the Guinea Pig Ileum via the Opioid Receptors

K. Taniyama, I. Sano, S. Nakayama, S. Matsuyama, K. TAKEDA, C. YOSHIHARA, AND C. TANAKA

1588 Flow-Cytometric DNA Content Analysis of Esophageal Squamous Cell Carcinomas

M. RobaszKiewicz, B.J. Reid, A. Volant, J.M. Cauvin, P.S. RABINOVITCH, AND H. GOUEROU

1594 Loss of Interleukin-2-Producing Intestinal CD4 + T Cells in Inflammatory Bowel Disease

K. Kusugami, T. MatsuURA, G.A. West, K.R. Youngman,

D. RACHMILEWITZ, AND C. FIOCCHI

1606 Sensorial and Intestinointestinal Reflex Pathways in the Human Jejunum

J.-M. RouILLON, F. AzPIROZ, AND J.-R. MALAGELADA

1613 Modification of the Effects of Blood on Amino Acid Metabolism by Intravenous Isoleucine

N.E.P. Deutz, P.L.M. ReIJVEN, M.C.F. Bost, C.L.H. van Berlo, AND P.B. SOETERS

1621 Enhanced Perception of Physiological Intestinal Motility in the Irritable Bowel Syndrome J.E. KELLOW, G.M. ECKERSLEY, AND M.P. JONES

\section{LIVER, PANCREAS, AND BILIARY TRACT}

1628 Gas in Gallstones: Quantitative Determinations and Possible Effects on Fragmentation by Shock Waves N. VAKIL AND E.C. EVERBACH

1635 The Antiinflammatory Effect of Dopamine in Alcoholic Hemorrhagic Pancreatitis in Cats N.D. Karanjia, A.L. Widdison, F.J. Lutrin, Y.-B. Chang, AND H.A. REBER

1642 A Prospective Controlled Study of the Risk of Bacteremia in Emergency Sclerotherapy of Esophageal Varices H. HO, M.J. ZUCKERMAN, AND C. WASSEM

1649 Patterns of Hepatitis Delta Virus Reinfection and Disease in Liver Transplantation

A. Ottobrelli, A. Marzano, A. Smedile, S. Recchia, M. SAlizzoni, C. Cornu, M.E. Lamy, J.B. OtTe, B. DE Hemptinne, A. Geubel, M. Grendele, M. Colledan,

D. Galmarini, G. Marinucci, C. Di Giacomo, S. Agnes,

F. BONINO, AND M. RIZZETTO

1656 Spontaneous Bacterial Peritonitis in Patients With Hepatitis B-Related Cirrhosis and Hepatocellular Carcinoma

S.-S. WANG, Y.-T. TSAl, S.-D. LeE, H.-T. Chen, C.-W. LU, F.-Y. LEE, J.-S. JENG, Y.-C. LIU, AND K.-J. LO

1663 Regional Orientation of Actin Filaments in the Pericanalicular Cytoplasm of Rat Hepatocytes M. ISHII, H. WASHIOKA, A. TONOSAKI, AND T. TOYOTA 
1673 Acute Infusions of Bile Salts Increase Biliary Excretion of Iron in Iron-Loaded Rats

P. LÉvY, M. Dumont, P. BRissot, A. Letreut, A. Favier,

Y. DEUGNIER, AND S. ERLINGER

1680 Differential Inhibition of Individual Human Liver Cytochromes P-450 by Cimetidine

R.G. KNODELL, D.G. BROWNE, G.P. GWOZDZ, W.R. BRIAN, AND F.P. GUENGERICH

1692 Experimental Evaluation of an Endoscopic Balloon for Manometry of Esophageal Varices

P. GerTsCh, A.M. Wheatley, R. Maibach, G.J. MadDERN, AND J.-N. VAUTHEY

1701 Occult Microlithiasis in 'Idiopathic' Acute Pancreatitis: Prevention of Relapses by Cholecystectomy or Ursodeoxycholic Acid Therapy

E. Ros, S. Navarro, C. Bru, A. Garcia-PugÉs, AND R. VALDERRAMA

1710 Glucagon Hinders the Effects of Somatostatin on Portal Hypertension M.P. Pizcueta, J.C. García-PagÁn, M. FernáNdez, R. Casamitjana, J. Bosch, and J. RodÉs

1716 Intraacinar Profiles of Alcohol Dehydrogenase and Aldehyde Dehydrogenase Activities in Human Liver I.P. MALY AND D. SASSE

1724 Antibodies to Hepatitis C Virus in Low-Risk Blood Donors: Implications for Counseling Positive Donors H.H. Hsu, M. Gonzalez, S.K.H. Foung, S.M. Feinstone, AND H.B. GREENBERG

\section{CASE REPORTS}

1728 Successful Orthotopic Liver Transplantation in a Patient With Refractory Biliary Candidiasis

K.B. NOACK, D.R. OSMON, K.P. BATTS, M. WILHELM,

R.A.F. KROM, AND K.D. LINDOR

1731 Acute Biliary-Vascular Fistula Following Needle Aspiration of the Liver M.S. VERHILLE AND S.J. MUÑOZ

1734 Severe Monochlorobenzene-Induced Liver Cell Necrosis G. Babany, J. Bernuau, A. Callleux, J.-F. Cadranel, C. Degott, S. Erlinger, and J.-P. Benhamou

1737 Severe Cholestatic Jaundice Associated With Piroxicam K.S. Hepps, G.M. Maliha, R. Estrada, and R.W. Goodgame

\section{EDITORIALS}

1741 Liver Transplantation: A Model for the Transmission of Hepatitis Delta Virus

W.S. MASON AND J.M. TAYLOR

\section{SELECTED SUMMARIES}

1744 Laparoscopic Treatment of Duodenal Ulcer: A Plea for Clinical Trials

1745 Alcohol Abuse and Liver Disease: True, True, but Not Necessarily Related

1747 Sphincter of Oddi Manometry in Patients With Possible Sphincter of Oddi Dysfunction

1748 Palliation of Advanced Esophageal Cancer: A (Laser) Light at the End of the Tunnel

1750 Is Exercise Good for Gastrointestinal Function?

\section{BOOK REVIEWS}

\section{CORRESPONDENCE}

1754 Extracorporeal Shock-Wave Lithotripsy for the Management of Bile Duct Stones: Is It Always a Safe Procedure?

1755 Microvillus Inclusion Disease

1756 Hyperplastic Polyps Do Not Predict Adenomatous Polyps

1757 A Role for NMR in Alcoholism?

1758 Whither Biliary Sludge-Do You Exist?

1759 Helicobacter pylori in Autoimmune Gastritis

1759 Propranolol for Prophylactic Treatment of a First Variceal Hemorrhage

1761 Intestinal Lymphangiectasia: Lack of Efficacy of Antiplasmin Therapy?

1761 CORRECTIONS

1762 NOTICES

1763 SPECLAL NOTICE

1768 AUTHOR INDEX TO VOLUME 101

1781 SUBJECT INDEX TO VOLUME 101 


\title{
Presence of Atrial Natriuretic Factor Prohormone in Enterochromaffin Cells of the Human Large Intestine
}

\author{
ALEXANDER L. GERBES, WALTER NATHRATH, MARC CANTIN, \\ and HEIKO DENECKE \\ Departments of Pathology and Surgery, Medizinische Klinik II, Klinikum Großhadern, \\ University of Munich, Munich, Germany; and Clinical Research Institute, Montreal, Quebec, \\ Canada
}

Atrial natriuretic factor is a hormone intimately involved in water and salt homeostasis. The heart constitutes the major but not exclusive site of synthesis of this hormone. Among other functions, the gastrointestinal tract has endocrine functions, plays an important role in volume regulation of the body, and seems to be a target organ for atrial natriuretic factor. Therefore, the presence of atrial natriuretic factor was investigated in the human gut. Immunoreactive atrial natriuretic factor was found in intraoperatively obtained samples of normal human colon. Acidic extracts of human large intestine contained about $0.4 \mathrm{pmol} / \mathrm{g}$ wet wt of atrial natriuretic factor. Analysis of atrial natriuretic factor immunoreactivity by gel-filtration and reversephase high-performance liquid chromatography showed that about $65 \%$ of the immunoreactivity corresponded to the atrial natriuretic factor prohormone and about $35 \%$ corresponded to the C-terminal $\mathrm{ANF}_{99-126}$. Immunohistochemistry showed atrial natriuretic factor prohormone location in enterochromaffin cells of the colon mucosa. Altogether, these findings show the presence of atrial natriuretic factor prohormone in enterochromaffin cells of the human large intestine and may suggest this organ as a site of atrial natriuretic factor synthesis in humans.

A trial natriuretic factor (ANF) is involved in salt and water homeostasis. It was first discovered in mammalian atrial myocytes, where it is synthesized and stored as a 126-amino-acid prohormone $(1,2)$. Upon appropriate stimulation, the prohormone is cleaved and released into the circulation where the C-terminal 28-amino-acid peptide $\mathrm{ANF}_{99-126}$ has been identified as a biologically active hormone $(3,4)$.
Subsequently, the presence of ANF has been determined in several tissues other than the heart (5-9), and recently it has been discovered in guinea pig and rat intestine $(10,11)$. The gastrointestinal tract plays an important role in volume regulation. Moreover, it seems to be a target organ for ANF with specific ANF binding sites (12-17). These findings, together with the endocrine properties of the gut (18-21), a major organ under endocrine control, might suggest a role of ANF in the intestine. Therefore, the aim of this study was to investigate the presence of ANF in the intestines of human subjects.

\section{Materials and Methods}

\section{Tissues}

Large intestinal tissue was obtained from 14 human subjects during surgery for the resection of tumors of the colon. Segments of nontumorous tissue (1-2 g) were washed with $4^{\circ} \mathrm{C}$ saline immediately after resection and were added to $4 \mathrm{~mL}$ of $0.1 \mathrm{~N} \mathrm{HCl}$ for extraction or were fixed in Bouin's fluid for immunohistochemistry.

\section{Extraction Procedure}

Tissue sections were boiled in $0.1 \mathrm{~N} \mathrm{HCl}$ in a microwave oven for 5 minutes and were subsequently homogenized with a polytron for 30 seconds. The resulting homogenate was boiled for another 5 minutes and centrifuged subsequently for 30 minutes at $4^{\circ} \mathrm{C}(20,000 \times g)$. The supernatant was applied to small columns filled with

Abbreviations used in this paper: ANF, atrial natriuretic factor; proANF, atrial natriuretic factor prohormone; TFA, trifluoroacetic acid.

(c) 1991 by the American Gastroenterological Association 0016-5085/91/\$3.00 
amberlite XAD-2 adsorbent resin (Serva, Heidelberg, Germany). The columns were washed with $0.1 \%$ trifluoroacetic acid (TFA) and eluted with $4 \mathrm{~mL}$ of $80 \%$ acetonitrile in $0.1 \%$ TFA. The eluates were lyophilized for further analysis.

\section{Radioimmunoassay and Recovery Determination}

The radioimmunoassay (RIA) was performed as described previously $(22,23)$; antibody Toni III (gift of R. Arendt) directed against the carboxy terminus of ANF recognizes $\mathrm{ANF}_{59.126}$ as well as the ANF prohormone (proANF). Recovery of immunoreactive ANF was evaluated by adding 250 or $500 \mathrm{fmol}$ of $\mathrm{ANF}_{99-126}$ or proANF 2 2-126 (gifts of Drs. Schöne, Preibisch, and Seipke, Höchst AG, Frankfurt, Germany) to the acidic tissue homogenate and performing extraction and separation procedures.

\section{Chromatographic Analysis of Atrial Natriuretic Factor Immunoreactivity}

Gel filtration. The lyophilized extract of colonic tissue was dissolved in $250 \mu \mathrm{L}$ of $0.1 \%$ TFA and loaded on a Sephadex G 50 column $(860 \times 16 \mathrm{~mm}$; Pharmacia, Uppsala, Sweden). The dynamic phase was $0.1 \mathrm{~N}$ acetic acid, the flow rate was $10 \mathrm{~mL} / \mathrm{h}$, and the fraction size was $2.5 \mathrm{~mL}$. Calibration was performed with albumin $\left(\mathrm{V}_{0}\right)$, vitamin $B_{12}$ $\left(\mathrm{V}_{1}\right)$, proANF ${ }_{2-126}$, and $\mathrm{ANF}_{99 \cdot 126}$.

Reverse-phase high-performance liquid chromatography. An aliquot of the pooled lyophilized fractions obtained by gel filtration was taken up in $50 \mu \mathrm{L} 0.5 \%$ TFA and loaded on a high-performance liquid chromatography (HPLC) $\mathrm{C}_{8}$ column $(5 \mu \mathrm{m}, 750 \times 4.6 \mathrm{~mm}$; Beckman Instruments, San Ramon, CA). Elution was performed with a linear gradient of acetonitrile $(20 \%-55 \%, 55$ minutes) in $0.1 \%$ TFA (flow rate, $0.5 \mathrm{~mL} / \mathrm{min}$ ). Calibration of the column was carried out with $\mathrm{ANF}_{99 \cdot 126}$ and proANF ${ }_{2 \cdot 126}$.

\section{Immunohistochemistry}

Colonic tissue specimens fixed in Bouin's fluid were dehydrated in alcohols and embedded in paraffin. An indirect immunoperoxidase method was carried out as previously described (25). In brief, $5-\mu \mathrm{m}$ sections of the Bouin-fixed, paraffin-embedded tissues were dewaxed in xylene and rehydrated through graded alcohols. Endogenous peroxidase activity was quenched by sequential treatment with $7.5 \%$ hydrogen peroxidase, $2.28 \%$ periodic acid, and $0.02 \%$ sodium borohydride. After overlaying the tissue in $2 \%$ normal goat serum, the specific antibodies were applied as follows: antibody Toni III, reacting with both proANF and $\mathrm{ANF}_{99.126}$, was diluted in phosphate-buffered saline (PBS) at a ratio of 1:400; antibody GT-23 (24), raised against the N-terminal fragment of proANF and reacting with the prohormone but not with $\mathrm{ANF}_{99 \cdot 126}$, was used in a 1:100 dilution; and the mouse monoclonal antibody raised against human chromogranin [LK $2 \mathrm{H} \mathrm{10;} \mathrm{(26)]} \mathrm{was} \mathrm{diluted}$
1:200. Incubation time was 2 hours at $37^{\circ} \mathrm{C}$ for each antibody. After washing in PBS, peroxidase-conjugated goat anti-rabbit immunoglobulin (Ig) $\mathrm{G}$ or goat anti-mouse IgG, diluted 1:250 and 1:1800, respectively, was applied for 5 minutes at $22^{\circ} \mathrm{C}$. Peroxidase reaction was visualized with aminoethylcarbazole, and hematoxylin was used to counterstain the nuclei. Controls included substitution of first and/or second antibody by PBS, normal mouse serum, or normal rabbit serum.

\section{Materials}

Human $\mathrm{ANF}_{99.126}$ was purchased from Nova Biochem, Läufelfingen, Switzerland; rat proANF ${ }_{2-126}$ was a gift from Drs. Schöne, Preibisch, and Seipke, Höchst AG, Frankfurt, Germany. ${ }^{125}$ I-iodinated $\mathrm{ANF}_{99 \cdot 126}$ was obtained from Biotrend, Cologne, Germany (sp act, $2000 \mathrm{Ci} / \mathrm{mmol}$ ). Antibody Toni III was a gift from R. Arendt, Medizinische Klinik I, Klinikum Großhadern, University of Munich, Munich, Germany; antibody GT-23 was provided by Drs. M. Cantin and G. Thibault, Clinical Research Institute, Montreal, Quebec, Canada. Amberlite XAD resin and sodium borohydride were obtained from Serva, Heidelberg, Germany. Normal goat, rabbit, and mouse sera and peroxidase goat anti-mouse IgG were obtained from Nordic Biogenzia, Bochum, Germany. Hydrogen peroxide and periodic acid were obtained from Merck, Darmstadt, Germany. Peroxidase goat anti-rabbit IgG, aminoethylcarbazole, and all other chemicals were obtained from Sigma, Taufkirchen, Germany.

\section{Results}

Large intestine tissue samples preextracted by XAD resin and purified by Sephadex G 50 gel filtration contained $0.4 \mathrm{pmol} / \mathrm{g}$ wet wt ANF immunoreactivity. Recovery rates of $\mathrm{ANF}_{99-126}$ and proANF 2 -126 were $27 \%$ and $21 \%$, respectively. After Sephadex G 50 gel filtration of the tissue extracts, the majority of ANF immunoreactivity coeluted with the prohormone (Figure $1 A$ ). When the ANF fractions obtained by gel filtration were subjected to reverse-phase HPLC, about $65 \%$ of the immunoreactivity coeluted with the prohormone and $35 \%$ with $\mathrm{ANF}_{99-126}$ (Figure $1 B$ ).

The localization of ANF immunoreactivity was analyzed by immunohistochemistry. The antibody Toni III, directed against both the prohormone and the $\mathrm{ANF}_{99-126}$ segment, showed specific intracytoplasmic staining of single epithelial cells within the colon mucosa (Figure $2 A$ ). On parallel sections, virtually identical staining patterns were achieved using antibody GT-23 (Figure $2 B$ ) and antibody against chromogranin (Figure $2 C$ ). No immunostaining was seen at other locations, particularly not in stromal or plasma cells. Controls were always negative. 

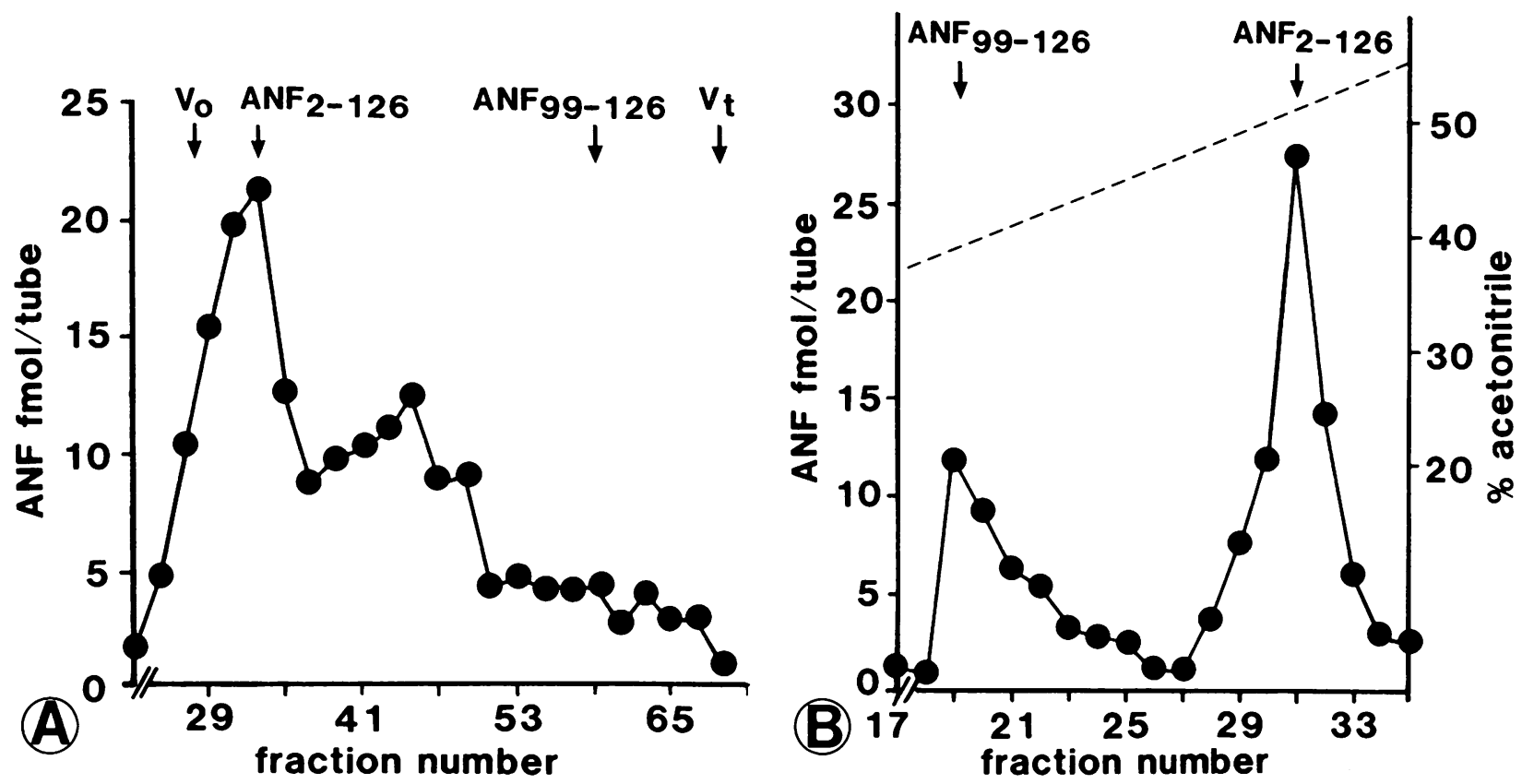

Figure 1. Characterization of ANF immunoreactivity.

A. Separation of ANF immunoreactivity in extracted colonic tissue samples by Sephadex $\mathrm{G} 50$ gel filtration. Calibration was performed with albumin $\left(\mathrm{V}_{\mathrm{o}}\right)$, vitamin $\mathrm{B}_{12}\left(\mathrm{~V}_{\mathrm{t}}\right)$, proANF $\mathrm{An}_{2 \cdot 126}$, and $\mathrm{ANF}_{99 \cdot 126}$. The majority of $\mathrm{ANF}$ immunoreactivity elutes in the range of proANF ${ }_{2 \cdot 126}$.

$B$. Characterization of the ANF immunoreactivity obtained by reverse-phase HPLC. About $65 \%$ of the immunoreactivity coelutes with proANF ${ }_{2 \cdot 126}$, whereas about $35 \%$ coelutes with the C-terminal $\mathrm{ANF}_{99.126}$.

\section{Discussion}

Initially the cardiac atria were considered to be the major source of ANF synthesis. However, subsequent reports found evidence for release of ANF in organs other than the heart $(5,6)$, and recently the presence of ANF has been shown in the intestine of the guinea pig and the rat $(10,11)$. Because the intestinal tract plays an important role in fluid regulation of the body, this finding, together with the demonstration of ANF binding sites in the gut $(12,14,17)$, suggested a possible role of this hormone in mammalian intestinal fluid absorption. Indeed, in various species, ANF has been shown to influence intestinal fluid and electrolyte handling $(13,15,16,27)$, whereas in others there was no effect $(28,29)$.

In the present study we found evidence for the presence of ANF prohormone in enterochromaffin cells of the human large intestine. This assumption is based on the following findings:

1. Atrial natriuretic factor immunoreactivity could be determined in extracted and purified colonic tissue samples of human subjects.

2. High-performance liquid chromatography analysis showed elution of the majority of the ANF immunoreactivity with the ANF prohormone. About one third of the immunoreactivity coeluting with
$\mathrm{ANF}_{99-126}$ might be due to degradation of the prohormone, which occurs rapidly in the gut (10).

3. Immunohistochemical staining with two different antibodies showed the presence of ANF prohormone in cells of the large intestine. The same cell type was stained with the antibody against chromogranin, highly suggesting that ANF immunoreactivity and most likely ANF synthesis is localized in enterochromaffin cells.

Enterochromaffin cells contribute to the endocrine regulation of the gut by containing and releasing various hormones $(30,31)$, and the biosynthesis and secretion of ANF has been shown in chromaffin cells of the adrenal glands (32).

In the present study we examined colonic tissue, but we have also found ANF immunoreactivity in tissue extracts of the jejunum and the ileum (data not shown). Recently, immunohistochemical evidence for ANF was found in biopsy samples of various parts of the gastrointestinal tract, but characterization of the ANF immunoreactivity or the ANF-containing cells was not performed (33). Thus, the regional distribution, cellular localization, and characterization of ANF immunoreactivity in other parts of the human intestine remains to be elucidated.

Altogether, our results for the first time suggest that 
Figure 2. Immunohistochemistry in a sigmoid colonic tissue sample. All three figures show $5-\mu \mathrm{m}$ parallel paraffin sections of a Bouin-fixed sigmoid colon tissue block with indirect immunoperoxidase reactions stained with aminoethylcarbazole and with nuclear hematoxylin counterstaining (original magnification $\times 560$ ).

A. Antibody Toni III, which recognizes both proANF and $\mathrm{ANF}_{99.126}$, shows strong specific immunostaining of cytoplasm of single cells within the mucosa epithelium.

B. Antibody GT-23, which reacts with proANF but not with $\mathrm{ANF}_{99 \cdot 126}$, shows the same pattern and distribution of specific immunostaining as shown in $A$.

$C$. The antibody against chromogranin shows the specifically stained enterochromaffin cells with a virtually identical staining and distribution pattern as shown in $A$ and $B$, suggesting that proANF is present in enterochromaffin cells of the human colon.
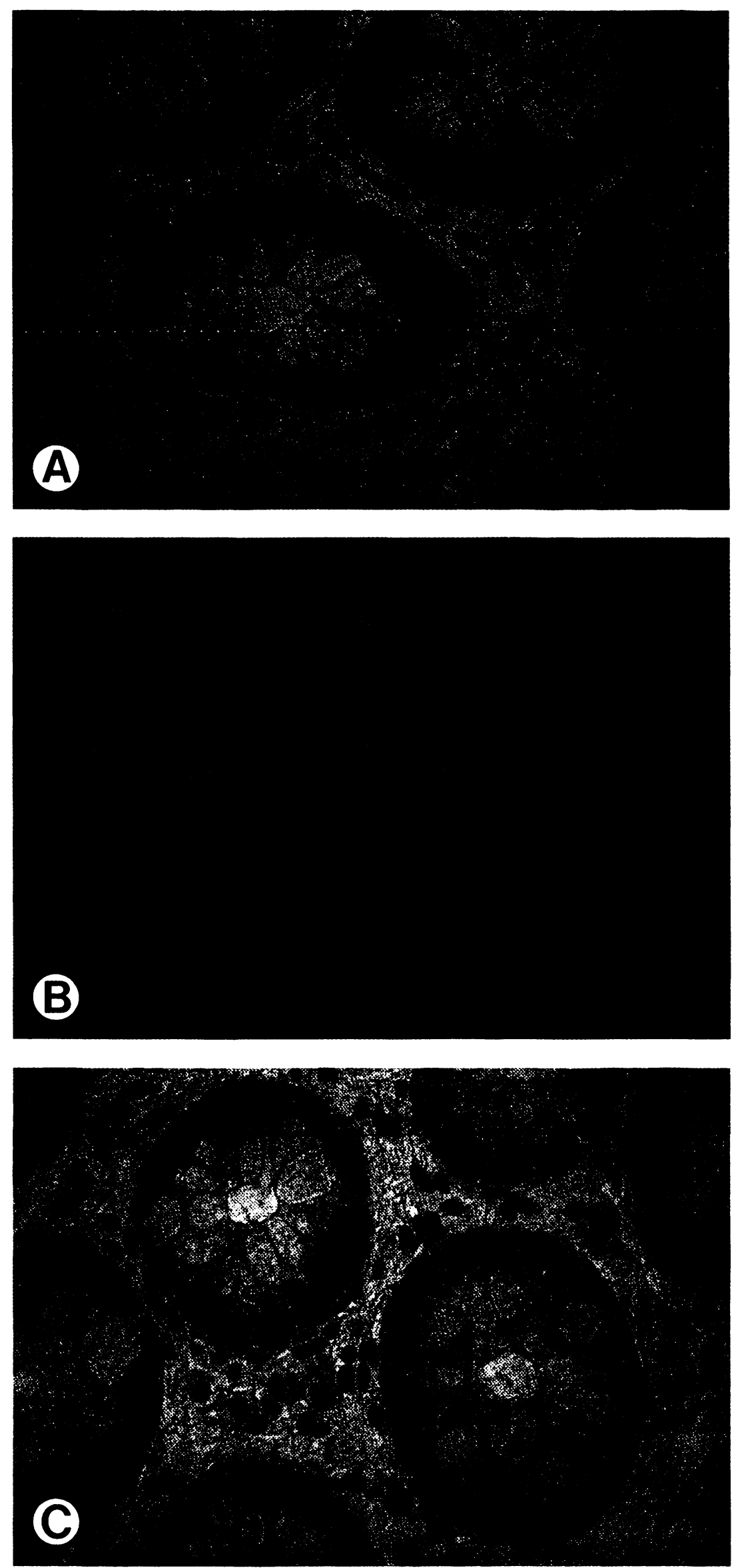
the large intestine is a site of ANF synthesis in humans. The physiological and pathophysiological implications of this finding could be of considerable interest.

\section{References}

1. De Bold AJ. Atrial natriuretic factor: a hormone produced by the heart. Science 1985;230:767-770.

2. Cantin M, Genest J. The heart and the atrial natriuretic factor. Endocr Rev 1985;6:107-127.

3. Schwartz D, Geller DM, Manning PT, Siegel NR, Fok KF, Smith CE, Needleman P. Ser-leu-arg-arg-atriopeptin III: the major circulating form of atrial peptide. Science 1985;229:397-400.

4. Thibault G, Lazure C, Schiffrin EL, Gutkowska J, Cartier L, Garcia R, Seidah NG, Chrétien M, Genest J, Cantin M. Identification of a biologically active circulating form of atrial natriuretic factor. Biochem Biophys Res Commun 1985;130:981986.

5. Gutkowska J, Nemer M. Structure expression and function of atrial natriuretic factor in extraatrial tissues. Endocr Rev 1989;10:519-536.

6. Vollmar AM. Atrial natriuretic peptide in peripheral organs other than the heart. Klin Wochenschr 1990;68:699-708.

7. Cantin M, Gutkowska J, Thibault G, Milne RW, Ledoux S, Minli S, Chapeau C, Garcia R, Hamet P, Genest J. Immunocytochemical localization of atrial natriuretic factor in the heart and salivary glands. Histochemistry 1984;80:112-127.

8. Mc Kenzie, Tanaka T, Misono N, Inagami T. Immunocytochemical localization of atrial natriuretic factor in the kidney, adrenal medulla, pituitary and atrium of the rat. J Histochem Cytochem 1985;338:828-832.

9. Morii N, Nakao K, Itoh H, Shiono S, Yamada T, Sugawara A, Saito Y, Mukoyama M, Arai H, Sakamoto M, Imura H. Atrial natriuretic polypeptide in spinal cord and autonomic ganglia. Biochem Biophys Res Commun 1987;145:198-200.

10. Vollmar AM, Friedrich A, Sinowatz F, Schulz R. Presence of atrial natriuretic peptide-like material in guinea pig intestine. Peptides 1988:9:965-971.

11. Vuolteenaho O, Arjamaa O, Vakkuri T, Maksniemi T, Nikkilä L, Kangas J, Puurunen J, Ruskoaho $H$, Leppäluoto J. Atrial natriuretic peptide (ANP) in rat gastrointestinal tract. FEBS Lett 1988;33:79-82.

12. Bianchi C, Gutkowska J, Thibault G, Garcia R, Genest J, Cantin M. Radioautographic localization of ${ }^{125} \mathrm{I}$ atrial natriuretic factor (ANF) in rat tissues. Histochemistry 1985;82:441-452.

13. Kanai Y, Ohnuma N, Matsuo H. Rat atrial natriuretic polypeptide increases net water, sodium and chloride absorption across rat small intestine in vivo. Jpn J Pharmacol 1987;45:713.

14. Mantyh CR, Kruger L, Brecha NC, Mantyh PW. Localization of specific binding sites for atrial natriuretic factor in peripheral tissues of the guinea pig, rat and human. Hypertension 1986;8: 712-721.

15. Moriarty HJ, Higgs MB, Lees M, Tonge A, Wardle TD, Warhurst $G$. Influence of atrial natriuretic peptide on mammalian large intestine. Gastroenterology 1990;98:647-653.

16. Seeber MA, Vidal MA, Carcio SM, Karara AL. Inhibition of water-sodium intestinal absorption by an atrial extract. Can J Pharmacol 1986;64:244-247.

17. Crane MR, O Hanley P, Waldman SA. Rat intestinal cell atrial natriuretic peptide receptor coupled to guanylate cyclase. Gastroenterology 1990;99:125-131.

18. Donnerer J, Holzer P, Lembeck F. Release of dynorphin, somatostatin and substance $P$ from the vasculary perfused small intestine of the guinea-pig during peristalsis. Br J Pharmacol 1984;83:919-925.

19. Pearse AGE. Peptides in brain and intestine. Nature $1976 ; 262$ : 92-94.

20. Schulzberg M, Höfkelt T, Nilsson G, Terenius L, Rehfeld JF, Brown M, Elde R, Goldstein M, Said S. Distribution of peptide and catecholamine-containing neurons in the gastrointestinal tract of rat and guinea pig: immunohistochemical studies with antisera to substance $P$, vasoactive intestinal polypeptide. enkephalins, somatostatin, gastrin/cholecystokinin neurotenside and dopamine $\beta$-hydroxylase. Neuroscience 1980;5:689744.

21. DelValle J, Yamada T. The gut as an endocrine organ. Annu Rev Med 1990;41:447-455.

22. Arendt RM, Gerbes AL, Ritter D, Stangl E. Molecular weight heterogeneity of plasma ANF in cardiovascular disease. Klin Wochenschr 1986;64(Suppl VI):97-102.

23. Gerbes AL, Arendt RM, Gerzer R, Schnizer W. Jüngst D, Paumgartner G, Wernze $H$. Role of atrial natriuretic factor, cyclic GMP and the renin aldosterone system in acute volume regulation of healthy human subjects. Eur J Clin Invest 1988;18: 425-429.

24. Thibault G, Murthy KK, Gutkowska J, Seidah NG, Lazure C, Chrétien $\mathrm{M}$, Cantin $\mathrm{M} . \mathrm{NH}_{2}$-terminal fragment of rat pro-atrial natriuretic factor in the circulation: identification, radioimmunoassay and half-life. Peptides 1988;9:47-53.

25. Nathrath WBJ, Schüppel RH, Wiebecke B, Björklund B. Distribution of tissue polypeptide antigen (TPA) in normal mucosa, in colitis ulcerosa, in adenomas and in carcinomas of the human colorectum. Acta Pathol Microbiol Immunol Scand 1988;96:509-518.

26. Wilson BS, Lloyd RV. Detection of chromogranin in neuroendocrine cells with a monoclonal antibody. Am J Pathol 1984;115: 458-468.

27. O'Grady SM. Cyclic nucleotide-mediated effects of ANF and VIP on flounder intestinal ion transport. Am J Physiol 1989;256: C142-146.

28. Barros GJ, Vakil N, Gutkowska J, Sellin J, Potter D. Atrial natriuretic factor and cyclic GMP: ion transport in rat colon in vitro and in vivo. Gastroenterology 1990;99:1153-1156.

29. Petritsch W, Holzer-Petsche U, Hinterleitner T, Kreis GJ. Intravenous atrial natriuretic peptide does not affect water and ion transport in the human small intestine. Eur J Clin Invest 1989;19:272-277.

30. Cetin Y. Enterochromaffin (EC-) cells of the mammalian gastroentero-pancreatic (GEP) endocrine system: cellular source of pro-dynorphin-derived peptides. Cell Tissue Res 1988;253:173179.

31. Coupland RE. The natural history of the chromaffin celltwenty-five years on the beginning. Arch Histol Cytol 1989; 52(Suppl):331-341.

32. Nguyen TT, Ong H, De Léan A. Secretion and biosynthesis of atrial natriuretic factor by cultured adrenal chromaffin cells. FEBS Lett 1988;231:393-396.

33. Ehrenreich H, Sinowatz F, Schulz R, Arendt RM, Goebel FD. Immunoreactive atrial natriuretic peptide (ANP) in endoscopic biopsies of the human gastrointestinal tract. Res Exp Med 1989;189:421-425.

Received August 20, 1990. Accepted December 23, 1990.

Address requests for reprints to: Alexander L. Gerbes, M.D., Medizinische Klinik II, Klinikum Großhadern, University of Munich, Marchioninistraße 15, D 8000 München 70, Germany.

Supported by the Deutsche Forschungsgemeinschaft (GE 576) and by the Deutsche Gesellschaft für Verdauungs- und Stoffwechselkrankheiten (Asche Stipendium to A.L.G.). 
This study was presented at the 91st Annual Meeting of the American Gastroenterological Association, May 1990, San Antonio, Texas, and was published in abstract form (Gastroenterology 1990;98:A495).

The authors thank Dr. R. M. Arendt for his support, in particular for providing the antibody Toni III. The technical assistance of $\mathrm{M}$.
Bauch and M. Koch is greatly appreciated. They are grateful for the help of the colleagues of the Department of Surgery, in particular Dr. Pratschke, for their cooperation in obtaining the tissue samples. The authors also thank E. Greiner for the illustrations, S. Sperl for the photographs, and M. Raab for the preparation of the manuscript. 